\title{
The Morphological Study of Wild and Farmed Olive Flounder (Paralichthys olivaceus): The Role of Indirect Selection within and between Populations
}

\author{
Jong-Won Park, Young-Mee Lee, Jae-Koo Noh, Hyun-Chul Kim, Choul-Ji Park, \\ In-Joon Hwang, Sung-Yeon Kim and Jeong-Ho Lee ${ }^{\dagger}$ \\ Genetics and Breeding Research Center, National Fisheries Research and Development Institute, \\ Geoje 656-842, Korea
}

\begin{abstract}
This study was conducted to analyze the difference of body types within and between wild and farmed populations of olive flounder Paralichthys olivaceus using measured records of morphological traits. The results showed that surveyed traits and standard deviation were $1,355 \pm 742 \mathrm{~g}$ of body weight, $48.01 \pm 7.79 \mathrm{~cm}$ of total length, and $40.96 \pm 6.80$ $\mathrm{cm}$ of body length. Also body height, body shape index and condition factor were $17.19 \pm 3.43 \mathrm{~cm}, 9.99 \pm 0.74$ and $11.16 \pm 1.54$, respectively. As result of least squares mean and standard error for each trait assumed in this study, those of farmed population showed significantly higher than those of wild population in all traits, exclusively in total length and body length $(\mathrm{p}<0.01)$. Particularly, the values of the body height and the body weight of the farmed population were higher than those of the wild population in the same total length. And the phenotypic correlation coefficients of the body weight, the total length, the body length and the body height showed strong positive correlation in all populations. These result suggested that morphological differences exist in farmed and wild flounder. Therefore, introduction of wild flounder is essential for the future production to improve the body type of farmed flounder, and parental fish should be chosen by considering selection of commercially important traits in the production process.
\end{abstract}

Key words : Body type, Wild, Farmed, Olive flounder, Morphological traits

\section{INTRODUCTION}

Olive flounder (Paralichthys olivaceus) is representative species of seawater farmed fish in Korea, which accounts for approximately $50 \%$ of the annual production of fish. For the aquaculture of olive flounder, artificial seed production research began since 1982 in Geoje Fisheries Hatchery Station, National Fisheries Research \& Development Institute (current Genetics \& Breeding Research Center, National Fisheries Research \& Development Institute). Embryos were obtained by adaptation in the land tank of natural spawning from

\footnotetext{
${ }^{\dagger}$ Corresponding author: Jeong-Ho Lee, Genetics and Breeding Research Center, National Fisheries Research and Development Institute, Geoje 656-842, Korea. Phone: +82-55-639-5801, Fax: +82-55-639-5809, E-mail: jhlee7124@korea.kr
}

wild flounder fertilized eggs since 1985 and can supply artificial seed technology and embryo. Jeju Island and Busan kijang, the water temperature is relatively high region in the winter began greatly increased the land tank aquaculture of olive flounder since the late 1980s and currently is being made across the country in Jeju Island and Wando. Started from a minority group in the 1980s, however, olive flounder aquaculture for over 30 years throughout several generations of inbreeding consists of genetic diversity being reduced, slowdown in growth, disease and environmental resistance degradation (Carvalho \& Haeser, 1994) as well as reported with the change of the body shape (National fisheries research \& development institute, 2006). To solve genetic problems of the domestic olive flounder aquaculture, Genetics \& Breeding Research Center cultured in 2004 from 2003 with the 
introduction of a wild mother group. As a result, olive flounder was improved growth rate and body shape and disseminated from 2010 in the field.

Morphological traits of the group may be determined by the innate genetic change as well as acquired factors such as the external environment (Parrish \& Saville, 1965; Myeong, 1992; Geng et al., 2000). Genetic methods in order to identify the characteristics of the group (Yoshida et al., 2000; Sekino et al., 2002; Hara \& Sekino, 2003; Liu et al., 2005; Jeong et al., 2009) are used, but a lot of morphological methods are also very useful (McClure \& Wickston, 1997; Resenberg, 2002; Her et al., 2006). Although morphological study may be the basis in the molecular biological studies of olive flounder, morphological research for the appearance was unknown until now. Therefore, the comparison of the phenotypic traits of wild and farmed olive flounder populations need to perform morphological studies. In this study, we were collected and measured wild and farmed olive flounder in several areas in order to provide basis data for improved domestic aquaculture.

\section{MATERIALS AND METHODS}

\section{Study populations}

A lot of 1,095 adult olive flounder specimens, based on a total of four populations from wild and five populations from farms were collected. Geographic locations, sample sizes, and nomenclature are given in Fig. 1 and Table 1.

\section{Experimental details and trait phenotyping}

Phenotypic data were recorded on four quantitative traits of wild and farmed populations of olive flounder (Fig. 2). These evaluations comprised body weight (BW in $\mathrm{g}$ ), total length (TL in $\mathrm{cm}$ ), body length (BL in $\mathrm{cm}$ ), and body height $(\mathrm{BH}$ in $\mathrm{cm})$. In addition, body shape index (BSI), condition factor (CF), and body length ratio (BLR) were calculated by the following equation:

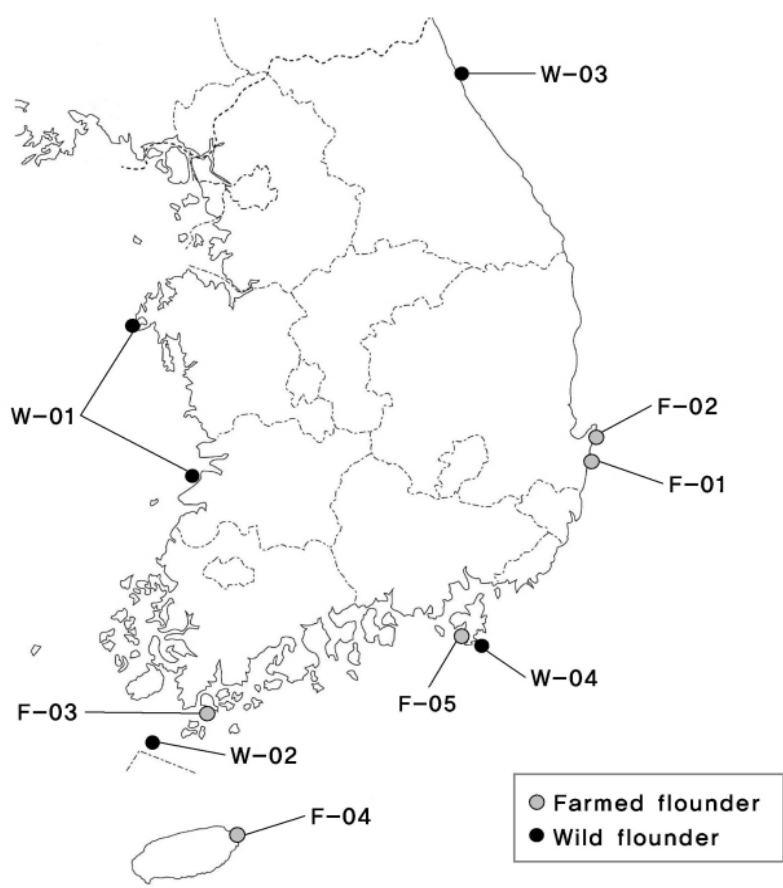

Fig. 1. Map showing the collecting locations of wild and farmed populations of olive flounder.

Table 1. Number of records by populations and collecting locations of olive flounder

\begin{tabular}{clc}
\hline \hline Population & \multicolumn{1}{c}{ Location } & Records \\
\hline & F-01 (Gyeongju) & 81 \\
Farmed & F-02 (Pohang) & 78 \\
flounder & F-03 (Wando) & 483 \\
& F-04 (Jeju) & 353 \\
& F-05 (Geoje) & 99 \\
\hline \multirow{3}{*}{ Wild } & W-01 (Taean, Buan) & 294 \\
flounder & W-02 (Chujado) & 78 \\
& W-03 (Sokcho) & 262 \\
& W-04 (Geoje) & 147 \\
\hline & Total & 1,876 \\
\hline
\end{tabular}

$$
\begin{aligned}
& B S I=\frac{B H(\mathrm{~cm})}{T L(\mathrm{~cm}) \times 0.357} \times 100 \\
& C F=\frac{B W \mathrm{~g})}{T L(\mathrm{~cm})^{3}} \times 1,000 \\
& B L R=\frac{B L(\mathrm{~cm})}{T L(\mathrm{~cm})} \times 100
\end{aligned}
$$




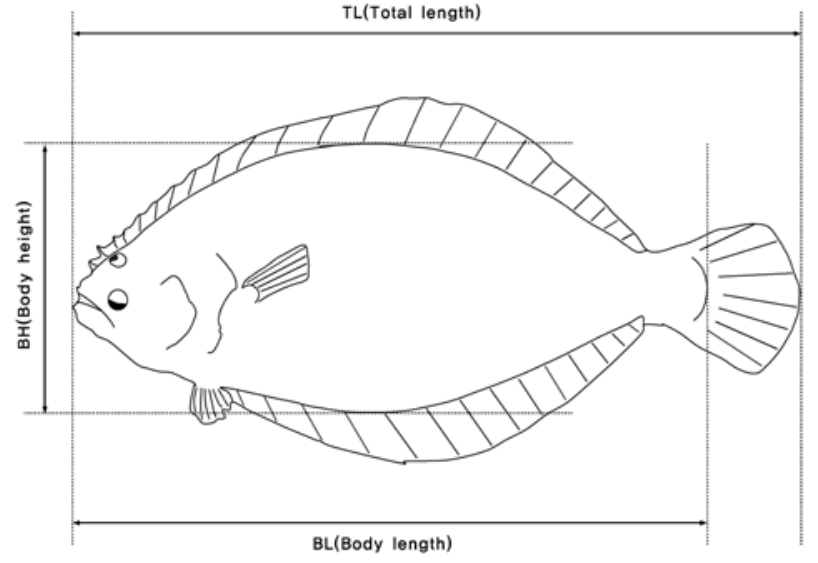

Fig. 2. Diagram showing the method of measuring the body parts of olive flounder.

\section{Statistical analysis of phenotypic data}

To assess the trait variability and the significant differences within and between populations, analysis of variance (ANOVA) was performed using the software
SAS version. 9.2 (SAS Institute, Cary, NC, USA). The character means were compared using the least significant differences (LSD) test at the $5 \%$ probability level. Furthermore, Pearson correlation coefficients were calculated using all investigated traits by SAS.

\section{RESULTS}

\section{Morphological analysis}

Morphological analysis of olive flounder showed that surveyed traits and standard deviation were $1,355 \pm 742$ $\mathrm{g}$ of body weight, $48.01 \pm 7.79 \mathrm{~cm}$ of total length, and $40.96 \pm 6.80 \mathrm{~cm}$ of body length. And body height, body shape index and condition factor were $17.19 \pm 3.43 \mathrm{~cm}$, $9.99 \pm 0.74$ and $11.16 \pm 1.54$, respectively (Table 2). BW (body weight; g), TL (total length; $\mathrm{cm}$ ), BL (body length; $\mathrm{cm}$ ), BH (body height; $\mathrm{cm}$ ), BSI (Body shape index), and CF (Condition factor) of wild and farmed

Table 2. Overall means of morphological traits and their standard deviations

\begin{tabular}{lcccccc}
\hline \multicolumn{1}{c}{ Source } & BW $(\mathrm{g})$ & TL $(\mathrm{cm})$ & BL $(\mathrm{cm})$ & BH $(\mathrm{cm})$ & BSI & CF \\
\hline Overall mean & $1,355.4$ & 48.01 & 40.96 & 17.19 & 9.99 & 11.16 \\
Standard deviation & 742.4 & 7.79 & 6.80 & 3.43 & 0.74 & 1.54 \\
\hline
\end{tabular}

Abbreviation: BW, Body weight; TL, Total length; BL, Body length; BH, Body height; BSI, Body shape index; CF, Condition factor.

Table 3. Least squares means and standard emors of the traits by divisions

\begin{tabular}{lcccccc}
\hline \hline \multicolumn{1}{c}{ Division } & BW $(\mathrm{g})$ & TL $(\mathrm{cm})$ & BL $(\mathrm{cm})$ & BH $(\mathrm{cm})$ & BSI & CF \\
\hline Farmed & $1556.0^{\mathrm{a}} \pm 15.2$ & $49.30 \pm 0.15$ & $42.01 \pm 0.14$ & $18.51^{\mathrm{a}} \pm 0.06$ & $10.47^{\mathrm{a}} \pm 0.01$ & $12.04^{\mathrm{a}} \pm 0.03$ \\
Wild & $1351.2^{\mathrm{b}} \pm 19.8$ & $49.56 \pm 0.20$ & $42.14 \pm 0.18$ & $16.73^{\mathrm{b}} \pm 0.08$ & $9.45^{\mathrm{b}} \pm 0.02$ & $10.06^{\mathrm{b}} \pm 0.04$ \\
\hline
\end{tabular}

Abbreviation: BW, Body weight; TL, Total length; BL, Body length; BH, Body height; BSI, Body shape index; CF, Condition factor.

Table 4. Phenotypic comelation coefficients among body weight, total length, body length, body height, body shape index and condition factor of olive flounder

\begin{tabular}{cccccc}
\hline \hline Source & BW & TL & BL & BH & BSI \\
\hline TL & 0.944 & & & & \\
BL & 0.941 & 0.995 & & & \\
BH & 0.943 & 0.926 & 0.917 & 0.645 & \\
BSI & 0.458 & 0.313 & 0.300 & 0.481 & 0.741 \\
CF & 0.478 & 0.239 & 0.234 & \\
\hline
\end{tabular}

Abbreviation: BW, Body weight; TL, Total length; BL, Body length; BH, Body height; BSI, Body shape index; CF, Condition factor. 
populations of olive flounder are given in Table 3. As result of least squares mean and standard error for each trait assumed in this study, those of farmed population showed significantly higher than those of wild population in all traits, exclusively in total length and body length $(\mathrm{p}<0.01)$. Particularly, two-factor anova (type III sums of squares) revealed that while farmed olive flounder (BW=1556.0 $\pm 15.2 \mathrm{~g}$; mean $\pm 95 \% \mathrm{CI}$ ) were significantly higher than wild (mean $\mathrm{TL}=1351.2 \pm 19.8 \mathrm{~g}$ ), there were no significant differences in mean TL and BL.

To determine the proportion of variation associated with differences in morphology, the two principal components were regressed against body height and body weight of each individual. PC2 was positively correlated with total length of all populations of olive flounder.

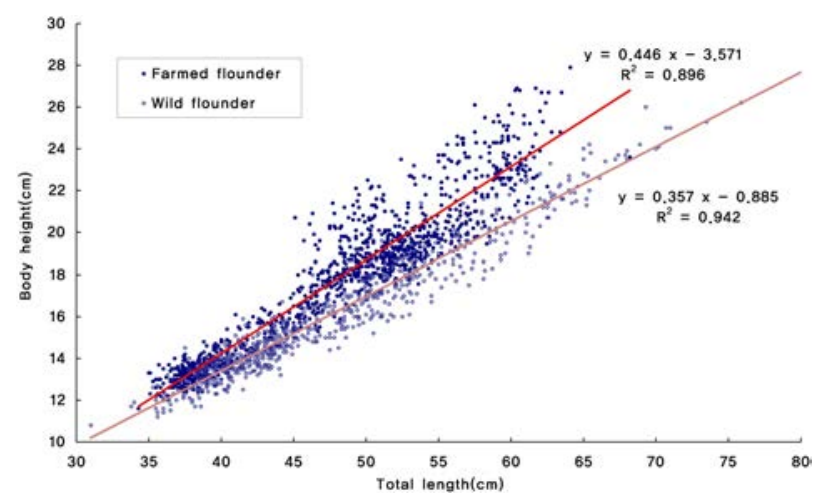

Fig. 3. Relationship between total length and body height by wild and farmed populations of olive flounder.

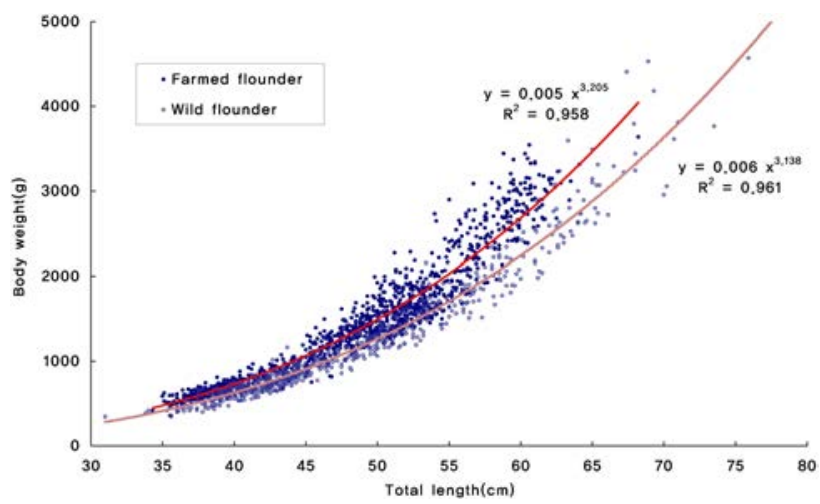

Fig. 4. Relationship between total length and body weight by wild and farmed populations of olive flounder.
Body height of wild and farmed populations of olive flounder linearly $(\mathrm{P}<0.05)$ increased with a increase in total length: $Y$ (body height $)=0.446 \times($ total length $)-3.571$ $\left(\mathrm{R}^{2}=0.896\right)$ and $\mathrm{Y}$ (body height $)=0.357$ (total length $)-$ $0.885\left(\mathrm{R}^{2}=0.942\right)$ (Fig. 3), respectively. In addition, body weight of wild and farmed populations of olive flounder linearly $(\mathrm{P}<0.05)$ increased with a increase in total length: $\mathrm{Y}$ (body weight) $=0.005$ (total length) ${ }^{3.205}\left(\mathrm{R}^{2}=0.958\right)$ and $Y$ (body weight $)=0.006$ (total length) ${ }^{3.138}\left(\mathrm{R}^{2}=0.961\right)$ (Fig. 4), respectively.

\section{Relationships between phenotypic traits}

Next, correlations between phenotypic traits were estimated. Traits recorded in wild and farmed olive flounder were BW (body weight; g), TL (total length; $\mathrm{cm}$ ), BL (body length; $\mathrm{cm}$ ), BH (body height; $\mathrm{cm}$ ), BSI (Body shape index), and CF (Condition factor). Phenotypic correlations between $\mathrm{BW}$ and $\mathrm{TL}, \mathrm{BW}$ and $\mathrm{BL}, \mathrm{BW}$ and $\mathrm{BH}, \mathrm{TL}$ and $\mathrm{BL}, \mathrm{TL}$ and $\mathrm{BH}$, and $\mathrm{BL}$ and $\mathrm{BH}$ were $0.944,0.941,0.943,0.995,0.926$, and 0.917 , respectively. These results showed that these traits were strongly related to each other. Strongly unfavourable phenotypic correlations were also obtained between TL and BSI (0.313) or CF (0.239).

\section{DISCUSSION}

The olive flounder is accounted for more than half of the domestic fish production and it is valued as the most competitive export species to the world market in the future. To improve the productivity and quality of olive flounder, research has been actively conducted for major economic traits in feed efficiency, growth and disease resistance (Sizemore \& Siegel, 1993; Gjedrem, 2000; Fjalestad et al., 2003; Kim et al, 2008; Kim et al, 2011).

Growth-oriented aquaculture of olive flounder was induced inbreeding since the start until now, and reduction of genetic diversity leads to decrease of growth and immunity and body shape changes. Japanese consumers 
prefer to olive flounder that fat-rich fin part and elliptical shape in the interview survey by the Korea exporters, on the other hand, Japanese buyers were likely to focus screening criteria such as shape, color and size (Korea maritime institute, 2005). Because body type is an important trait in Japan as well as in the world market, comparison of the group and regional body type between wild and farmed olive flounder was able to basic data for the improvement of farmed flounder body type.

In this study, coefficients of the growth-related traits such as body weight, total length and body length are higher in farmed olive flounder, it suggested that just one of the growth traits can be obtained the improved effect of the addition of other growth traits. However, correlation between the body weight and body index, total length and body index appeared somewhat lower, therefore should be considered appropriate weighted value of the body index for improvement of body type in the selection process of mother. Farmed and wild flounder were similar to total length and body length, but, in shape, body height and shape index of farmed flounder were significantly higher than those of wild flounder.

The regional population analysis of farmed and wild flounder showed that most farmed group were classified as high-body index, whereas all four wild group were classified as low-body index. These results suggested that morphological differences exist in farmed and wild flounder. Therefore, introduction of wild flounder is essential for the future production to improve the body type of farmed flounder, and parental fish should be chosen by considering commercial important traits such as growth, disease, environmental resistance, and feed efficiency in the production process. In addition, morphological studies should be made consistently for improving body type and export to Japan and the world market of olive flounder.

\section{ACKNOWLEDGEMENT}

This work was supported by a grant from the National
Fisheries Research and Development Institute (RP-2012AQ-122).

\section{REFERENCES}

Carvalho GR, Hauser L (1994) Molecular genetics and the stock concept in fisheries. Rev Fish Biol Fish 4:326-350.

Geng M, Li J, Xin X, Deng G, Xu J, Guan H (2000) The effects of pyridoxal phosphate on morphological changes in cultured Hippocampalneurons. J Ocean Univ Qingdao 30:249-254.

Fjalestad KT, Moen T, Gomez-Raya L (2003) Prospects for genetic technology in salmon breeding programmes. Aquac Res 34:397-406.

Gjedrem T (2000) Genetic improvement of cold-water species. Aquac Res 31:25-33.

Her YS, Lee KB, Her MK (2006) Morphological variability of the Japanese swimming Charybdis japonica populations. J Life Sci 16:672-675.

Hwang JW, Myeong JI (2010) An economic effect of the selective breeding program on the oliver flounder aquaculture. J Fish Busi Admi 41(1):113-128.

Hara M, Sekino M (2003) Efficient detection of parentage in a cultured Japanese flounder Paralichthy olivaceus using microsatellite DNA marker. Aquaculture 217: 107-114.

Jeong DS, Noh JK, Myeong JI, Lee JH, Kim HC, Park CJ, Min BH, Ha DS, Jeon CY (2009) Genetic variability comparison of wild populations and cultured stocks of flounder paralichthys olivaceus based on microsatellite DNA markers. Kor J Ichthyol 21(4):221-226.

Kim HC, Noh JK, Lee JH, Kim JH, Park CJ, Kang JH, Kim KK, Lee JG, Myeong JI (2008) Estimation of genetic parameters and reproductivity test of genetic evaluation for growth-related traits of olive flounder Paralichthys olivaceus at 180 days of Age. Kor Aqua Soc 21:317-324.

Kim HC, Noh JK, Lee JH, Park CJ, Min BH, Kim KK, 
Kim JH, Lee JG, Myeong JI (2011) Estimation of genetic parameters of growth-related traits from 11-month-old olive flounder (Paralichthys olivaceus) base population in which wild flounder broodstocks were introduced. J Anim Sci \& Tech 53:99-106.

Korea Maritime Institute (2005) Export business survey index. pp 78.

Liu Y, Chen S, Li B (2005) Assessing the genetic structure of three Japanese flounder (Paralichthys olivaceus) stocks by microsatellite markers. Aquaculture 243: 103-111.

McClure MR, Wicksten MK (1997) Morphological variation of species of the Edwardsii group of Alpheus in the Northern Gulf of Mexico and Northwestern Atlantic. J Crust Biol 17:480-487.

Myoung JG, Kim HS, Kim PK, Kim YU (1992) Morphological changes during starvation of larvae of left eye flounder, Paralichthys olivaceus. Kor J Ichthyol 4(1):20-28.

National Fisheries Research \& Development Institute (2006) Standard Manual of Olive Flounder Culture. Publisher Haein.

Parrish BB, Saville A (1965) The biology of the north- east atlantic herring populations. Ocean Mar Biol Ann Rev 3:323-373.

Resenberg MS (2002) Fiddler crab claw shape variations: a geometric morphometric analysis across the genus Uca. Biol J Linn Soc 75:147-162.

Sekino M, Hara M Taniguchi N (2002) Loss of microsatellite and mitochondrial DNA variation in hatchery strains of Japanese flounder Paralichthy olivaceus. Aquaculture. 213:101-122.

Sizemore FG, Siegel HS (1993) Growth, feed conversion, and carcass composition in females of four broiler crossesfed starter diets with different energy levels and energy to protein ratios. Poult Sci 72:22162228

Yoshida K, Takagi M, Tanaka M, Taniguchil N (2000) Genetic variability and divergence of wild and artificially raised Japanese flounder Paralichthys olivaceus inferred from microsatellite DNA analysis. Fish Gen Breed Sci 29:93-102.

(Received 1 December 2012, Received in revised form 18 December 2012, Accepted 23 December 2012) 